INTERNATIONAL JOURNAL OF MULTidisciplinARY RESEARCH AND ANALYSis

ISSN(print): 2643-9840, ISSN(online): 2643-9875

Volume 05 Issue 02 February 2022

DOI: 10.47191/ijmra/v5-i2-21, Impact Factor: 6.072

Page No. 381-385

\title{
Benefits and Challenges of Taking English Courses Abroad: A Case Study of FPT University Students
}

\author{
Hien Vo Ngoc \\ FPT University, Ho Chi Minh City - Vietnam
}

ABSTRACT: There are many different ways to learn English effectively, and joining English courses abroad is one of them. FPT University is implementing this method to improve students' English ability, contributing to strengthening the internationalization and globalization of this international standard university. From the actual research at FPT University, this article mentions the great benefits of the method, including (1) Students have a favorable environment to practice using English, (2) Students learn to live independently , (3) Enhance the experience of student life, and (4) Besides English, students have many opportunities to learn about many other things. In addition, the five most common challenges related to this method of English improvement were also found to be (1) Program costs are high, (2) Lack of confidence in the ability to use English, (3) Participants must get out of their "safe zone", (4) Participants must be away from loved ones for quite a long time, and (5) Participants may face safety risks. Since then, combined with the author's research, some suggestions have been made so that the program's quality is improved, more students can know and participate in the program.

KEYWORDS: Abroad, benefits, challenges, English courses, learn English, students

\section{INTRODUCTION}

As we all know, English is a global language (according to Rao, 2019). Many people around the world have been working hard to learn English to master this prevalent language. There are many different ways to acquire and use English, such as self-studying at home using apps, websites, and youtube, studying through schools or centers, foreign language clubs, community activities, etc. Not to be missed is studying English through short-term courses abroad.

At FPT University - Vietnam, English is very important in training. $100 \%$ of students enter the specialized study stage with an English level equivalent to IELTS 6.0. There are a total of 6 English levels for the preparatory stage; after taking the English placement test, students will know what level of English they have achieved and accordingly be placed in the appropriate class. With the orientation to enhance the experience of using language, many English courses in Australia, The Philippines, Singapore and Malaysia are held annually for students at the highest level, with the subject code TRS501.

\section{LITERATURE REVIEWS}

When it comes to the benefits of study abroad programs, there has been much research. These include Twombly et al. (2012), who analyzed the great benefits of studying abroad in a new global century. Many of the benefits of studying abroad have been covered in great detail and persuasiveness in this research. In addition, in the opposite direction, the difficulties encountered when studying abroad have also been studied by Trilokekar and Kukar (2021); being disoriented in one or more stages while abroad is one of the experiences inevitable and most challenging of all international students.

On a narrower scale, about the benefits of studying English abroad, we see research by quite a few researchers like Sasaki (2007); the author has analyzed the positive effects of traveling abroad learning in improving foreign language ability, mainly English writing skills. Alternatively, another study by Trentman (2013) also mentioned some issues of accessing and using Arabic and English during study abroad in Cairo, Egypt.

As for learning English at FPT University, according to Vo et al. (2020), there are quite a few challenges that a student of general English may have to face at this TRS501. A survey of 50 students and 3 faculty members found that the three most common challenges to students' reading comprehension at TRS501 were vocabulary, grammar, and inability to identify sentences answer. However, this study focuses on students who have studied this subject in Vietnam rather than abroad and only focuses on reading 


\section{Benefits and Challenges of Taking English Courses Abroad: A Case Study of FPT University Students}

comprehension. Therefore, this study focuses more deeply on the benefits and challenges of learning English through short-term study abroad programs.

\section{METHODOLOGY}

To elucidate the benefits and challenges of attending English courses abroad of FPT University students, the author has used a combination of both qualitative and quantitative methods. Specifically, the author collected information from 3 staff of the International Cooperation Department, who directly organized the above English study abroad programs and 50 students who had participated in the program. This study abroad program replaces taking the ETR501 course in Vietnam. The implementation method is face-to-face interviews and online surveys through Facebook, Zalo, and email. In addition, the author also relies on information from studies, books, and newspapers with topics related to the content being studied. From there, the author synthesizes, analyzes, compares, and contrasts to give the most objective and accurate results. The total duration of the study was 3 months. The ultimate aim is to highlight the benefits of the program in order to attract more students to the program. Besides, clarify the limitations the remaining disadvantages, challenges so that the program implementers can adjust and improve the program.

\section{RESEARCH RESULTS AND DISCUSSION}

To clarify the benefits of participating in English courses abroad, the author discussed with the human resources department of the International Cooperation Department, FPT University, and the results were four benefits. The main points are as follows: (1) Students have a favorable environment to practice using English, (2) Students learn to live independently, (3) Enhance the experience of student life, and (4) Besides English, students have many opportunities to learn about many other things. Based on these initial results, the author surveyed the agreement level of 50 students who had participated in the program, and the results were as shown in the following table and figure.

Table 1. Level of agreement about the benefits of taking English courses abroad

\begin{tabular}{|c|c|c|c|c|c|c|c|}
\hline \multirow[t]{2}{*}{ Benefit } & $\begin{array}{l}\text { Strongly } \\
\text { disagree }\end{array}$ & Disagree & $\begin{array}{l}\text { Neither } \\
\text { agree or } \\
\text { disagree }\end{array}$ & Agree & $\begin{array}{l}\text { Strongly } \\
\text { agree }\end{array}$ & \multirow[t]{2}{*}{$\begin{array}{l}\text { Total } \\
\text { Reply }\end{array}$} & \multirow[t]{2}{*}{$\begin{array}{l}\text { Total } \\
\text { Score }\end{array}$} \\
\hline & 1 & 2 & 3 & 4 & 5 & & \\
\hline $\begin{array}{l}\text { (1) Students have a favorable environment to } \\
\text { practice using English }\end{array}$ & 0 & 0 & 2 & 12 & 36 & 50 & 234 \\
\hline (2) Students learn to live independently & 0 & 2 & 0 & 15 & 33 & 50 & 229 \\
\hline (3) Enhance the experience of student life & 1 & 3 & 7 & 15 & 24 & 50 & 208 \\
\hline $\begin{array}{l}\text { (4) Besides English, students have many } \\
\text { opportunities to learn about many other things }\end{array}$ & 1 & 0 & 1 & 25 & 23 & 50 & 219 \\
\hline & & & & & & & 890 \\
\hline
\end{tabular}

This result clearly shows that, in general, 50 students surveyed have a high degree of agreement with the benefits that the author discussed with the people who directly organize the program. The highest benefit is that students have a favorable environment to practice using English, with a total score of 234. Especially, 36/50 students agree at the highest level, accounting for $72 \%$. This result is quite understandable because if students study English in Vietnam, the practice of using foreign languages will almost wholly stop when students leave the classroom. However, when studying abroad, students have many opportunities to practice listening, speaking, reading, or even writing skills in daily life, through daily activities such as shopping, going on a picnic, communicating with foreign roommates, etc. In addition, even during class hours, group discussions or pair work are also conducted in English - this is extremely difficult to do if their classmates are English. have the same nationality. In their study in 2020, Daif-Allah and Aljumah agreed with this view; trying to use the language learners are learning to communicate with classmates of different nationalities has great effect and promotes language mastery. Not only that, when studying abroad, direct interaction with native teachers, or at least teachers who do not speak the learners' native language, will also contribute to stimulating the development of students in terms of student language a lot. This view has been clarified by many researchers, such as Walkinshaw and Oanh (2014), Al-Khasawneh (2017), Mohammed (2018), etc.

As mentioned above, for students of FPT University, most students must complete this English learning phase in the first year. This means that their typical age is 18-19 years old, and they have just finished high school. In the context of Vietnamese culture, it 


\section{Benefits and Challenges of Taking English Courses Abroad: A Case Study of FPT University Students}

can be said that this is the first time in a Vietnamese person's life where he must learn to live independently; of course, this degree of independence is also quite different for individuals. So in the condition of being away from family, coming to a foreign country to learn English is a perfect opportunity for practicing an independent and more mature lifestyle. Agreeing with this view, Nielsen, in her study in 2014, said that studying abroad has made a significant contribution to promoting a person's maturation process. Going back to this study, up to $96 \%$ of the students surveyed agree and strongly agree with this great benefit of taking an English course abroad. Discussing more closely with two students who disagreed with the above view, the author concluded that both of these learners believe that independent life is mainly due to each person, not the impact of outside living.

In higher education orientation, the student experience is an essential factor that many universities and colleges need to aim for (Mupenzi, 2018). From this point of view, the author and three experts from the International Cooperation Department agreed that participating in a short-term English study abroad helped enhance student life experience a lot. However, such a course that lasts from 1 to 3 months may not be long enough for learners to experience many things in a new country, so 11 out of 50 students choose strongly disagree, disagree, and neutral, accounting for $22 \%$. However, nearly $50 \%$ of the respondents strongly agree with the point of view just presented among the remaining students. Those precious experiences can come from many things such as experiencing a comfortable life in a modern country, experiencing services that are not available, or very rare in Vietnam, such as means of transportation, entertainment, etc. For many students who are passionate about foreign films, this is an opportunity for them to truly experience the life of an international student as fully and as excitingly as possible.

Usually, students take an English course abroad, what they expect is to learn English and many other things. These values can come from their classroom, such as teamwork skills, presentation, persuasion, critical thinking, etc. Besides, students learn more about the culture, people, tourism, and many other areas of the host country. This brings many incredible benefits to learners, especially for students oriented to work in a multinational environment, work abroad, or even return to the country in which the student joined this program to work. Understanding and agreeing with this, up to $98 \%$ of the students asked to agree with the above point of view.

The benefits of short-term English study abroad are pretty obvious. However, coexisting with it are difficulties and challenges. Within the framework of this research, the challenges that students will face will be explored and presented in the following section.

Table 2. Common challenges that students face when taking English courses abroad

\begin{tabular}{|l|l|l|}
\hline Challenge & Number of students selected & Percentage \\
\hline (1) Program costs are high & 49 & 98 \\
\hline (2) Lack of confidence in the ability to use English & 38 & 76 \\
\hline (3) Participants must get out of their "safe zone" & 31 & 62 \\
\hline (4) Participants must be away from loved ones for quite a long time & 27 & 54 \\
\hline (5) Participants may face safety risks & 26 & 52 \\
\hline
\end{tabular}

The results from the table above show that the program's cost is the leading factor influencing learners' decision whether they can participate in the program or not, with $98 \%$ of students asked to choose this category. According to Chelliah et al. (2019), the cost of study abroad programs is one of the main factors affecting the decision to participate in the program and learners' satisfaction when studying abroad. It is understandable that when studying English in developed countries, the cost that learners have to pay is much or much higher. In the case of FPT University students, they can complete ETR501 in Vietnam with a tuition fee of about 550 USD, but if they apply for the program in Australia, this fee will double. In addition, students need to pay many other high fees, such as accommodation, transportation, airfare, other living expenses, etc.

The second in the list of the most common challenges that students often face when studying English abroad is a lack of confidence in their ability to use a foreign language even though they have previously studied English pretty much. This challenge accounts for $76 \%$. This difficulty can be explained by the past's lack of experience in learning English. In fact, many Vietnamese students may have studied English for quite a long time, 5, 10, even 15 years before that. However, when it comes to using it as a part of life because students have to live abroad for a certain period, it immediately becomes an invisible barrier. According to Nguyen (2019), in Vietnam, many people learn English to pass exams only, not to learn to use it, which explains the challenge mentioned above. Therefore, at FPT University, many efforts have been made to increase the practical use of English, but it is pretty difficult for all students to learn English in a relatively limited period, from 2 to 10 months.

The "safe zone" concept in this study is understood as familiar, comfortable, complete, and convenient for students. Many students face great difficulties when entering university; when this comfort zone gradually disappears, students need to be strong 


\section{Benefits and Challenges of Taking English Courses Abroad: A Case Study of FPT University Students}

enough to face more challenges, difficulties, and changes. That level of difficulty and novelty will become higher when students leave Vietnam and study in a foreign country. For that reason, in this survey, up to $64 \%$ of students surveyed chose this as one of the major challenges they face when studying abroad. In particular, in today's developed society, more and more attention is paid to learning, students become more and more cared for and pampered to focus on studying alone. This has many consequences, and not wanting to change for the better is one of the significant challenges associated with this challenge- Participants must get out of their "safe zone".

"Participants must be away from loved ones for quite a long time" was the next challenge chosen by 27 students, with a rate of $54 \%$. Through the study of related documents and in-depth discussions with these 50 students, the author concluded that in the context of Vietnamese culture, community cohesion had a profound impact on the lives of Vietnamese people, including students. Leaving family, friends, or lovers to study abroad is quite tricky and will make them lose their morale and concentration in studying (Ngoc, 2014). Along with this topic, homesickness has also been mentioned by Hendrickson and Aune (2011) in their research. Homesickness is one of the significant difficulties that international students face.

A final common challenge here is the safety risks that students may face while participating in the program. There are $52 \%$ of students choose this because when studying abroad, there are many potential risks that can happen to them. Such safety risks may occur due to a lack of adequate understanding of the laws, cultures, religions, and regulations of the host country, land, and school where students come. Moreover, even if students have made careful preparations about the above, the safety risk cannot be eliminated because there are many differences in laws, cultures, customs, etc., between countries and continents. In political instability, natural disasters or epidemics such as the COVID-19 pandemic, being unsafe or stuck in a foreign country, and being unable to return home are risks students may encounter while studying abroad for a short time.

\section{CONCLUSIONS AND RECOMMENDATIONS}

Regardless of the great benefits of a short-term study abroad program to learners, the above challenges need to be considered thoroughly. Then we offer solutions to improve the program. Because if we do not have these adjustments, the program's quality will still be stagnant, even in the context of the epidemic and political instability, and natural disasters in many places, the program will be reduced in terms of quality, and it cannot be ruled out that the program is canceled. In this study, the author has proposed several options that can improve the above challenges.

As mentioned above, the biggest problem is the cost difficulty; the disparity in prices in developed countries makes many students want, but they cannot participate in the program. Therefore, universities should consider adjusting fees, such as tuition fees, institution fees, accommodation fees, etc., at a reasonable cost. In the best case, these fees should not differ too much from studying in Vietnam; this would be a practical and effective measure in this regard. The school can also apply many forms such as tuition support free or reduced tuition for students participating in the program. In addition, schools can also support the cost of air tickets, accommodation, and even full scholarships for excellent students. Like some other exceptions when studying at the school, the University may also apply a scholarship or loan policy to provide financial support to students who enroll in the program. If these financial difficulties are removed, the student's decision to join the program will undoubtedly become a lot easier.

Next is the problem of increasing confidence in students, especially confidence in using English with foreigners and in an overseas environment. Educators need to have effective, practical, and appropriate measures so that students can cultivate this confidence right from the first days of learning English. It will be tricky for universities when the English learner they accept is now a student, but it is not easy. Senior and experienced professionals in English teaching need to pay more attention to the practicality of using this language, not just teaching so that learners can pass exams only.

It is not only the school's duty, but the family also needs to join hands in encouraging and facilitating students to step out of their "safe zone" as soon as possible. It is not only convenient for students to boldly participate in short-term study abroad programs such as studying English, but it also opens a new path ahead - the path of young, mature, and enthusiastic people. , dare to challenge and accept failure to get better every day. Related to this, parents who are overly protective of their children need to give more consideration to training their children to lead an independent life, have the right to self-determination, and take responsibility for themselves - from the minor things in everyday life to choosing the essential things in personal life. With this approach, the fourth challenge mentioned above is also solved.

Most risks are unintended and intended. However, in organizing the program, the organizers can also take many actions to minimize the possible damage caused by such risks. For example, it is necessary to be serious about training and supplementing with important information about law, politics, religion, culture, etc., students before sending them to a specific country. In organizing the program, it is necessary to arrange the school's personnel and coordinate with partners to follow up and support students in urgent cases. Enhance coordination among stakeholders so that information is complete and timely. In addition, the 


\section{Benefits and Challenges of Taking English Courses Abroad: A Case Study of FPT University Students}

requirements for buying insurance for the trip or vaccination for program participants should also be paid attention to. In addition, there are many other specific measures that schools need to prepare and implement for specific programs in different countries carefully.

\section{ACKNOWLEDGMENT}

To complete this research paper, the author has received much support from the staff of the international cooperation department and students studying at FPT University. Special thanks to you.

\section{REFERENCES}

1) Al-Khasawneh, F. M. (2017). A genre analysis of research article abstracts written by native and non-native speakers of English. Journal of Applied Linguistics and Language Research, 4(1), 1-13.

2) Chelliah, S., Khan, M. J., Krishnan, T., Kamarulzaman, M. E. B. M., \& Goh, N. E. (2019). Factors influencing satisfaction and revisit intention among international exchange students in Malaysia. Journal of International Education in Business.

3) Hendrickson, B., Rosen, D., \& Aune, R. K. (2011). An analysis of friendship networks, social connectedness, homesickness, and satisfaction levels of international students. International journal of intercultural relations, 35(3), $281-295$.

4) Mohammed, M. H. (2018). Challenges of learning English as a Foreign Language (EFL) by non-native learners. International Journal of Social Science and Economic Research, 3(4), 1381-1400.

5) Mupenzi, A. (2018). Educational resilience and experiences of African students with a refugee background in Australian tertiary education. Australasian Review of African Studies, The, 39(2), 122-150.

6) Ngọc, T. T. M. (2014). Đạo đức sinh viên Việt Nam thực trạng và giải pháp. Viện Hàn Lâm Khoa học xã hội Việt Nam, Khoa học xã hội Việt Nam, 2.

7) Nguyen, H. C. (2019). Motivation in learning English language: a case study at Vietnam national university, Hanoi. European Journal of Educational Sciences, 6(1), 49-65.

8) Nielsen, K. (2014). Study abroad: perspectives on transitions to adulthood (Doctoral dissertation, University of Sussex).

9) Rao, P. S. (2019). The role of English as a global language. Research Journal of English, 4(1), 65-79.

10) Sasaki, M. (2007). Effects of study-abroad experiences on EFL writers: A multiple-data analysis. The Modern Language Journal, 91(4), 602-620.

11) Trentman, E. (2013). Arabic and English during study abroad in Cairo, Egypt: Issues of access and use. The Modern Language Journal, 97(2), 457-473.

12) Trilokekar, R. D., \& Kukar, P. (2011). Disorienting experiences during study abroad: Reflections of pre-service teacher candidates. Teaching and Teacher Education, 27(7), 1141-1150.

13) Twombly, S. B., Salisbury, M. H., Tumanut, S. D., \& Klute, P. (2012). Study Abroad in a New Global Century--Renewing the Promise, Refining the Purpose. ASHE higher education report, 38(4), 1-152.

14) Vo, H. V., Ho, N. D., \& Ho, T. K. Y. (2020). A study on the most common challenges of reading comprehension faced by General-English students in TRS501 course at HCMC FPT University (Doctoral dissertation, FPTU HCM).

15) Walkinshaw, I., \& Oanh, D. H. (2014). Native and non-native English language teachers: Student perceptions in Vietnam and Japan. Sage Open, 4(2), 2158244014534451.

16) Wang, I. K. H. (2018). Learning vocabulary strategically in a study-abroad context. In Learning Vocabulary Strategically in a Study Abroad Context (pp. 231-268). Palgrave Macmillan, Cham.

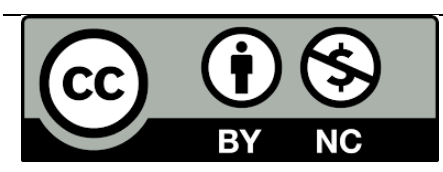

There is an Open Access article, distributed under the term of the Creative Commons Attribution - Non Commercial 4.0 International (CC BY-NC 4.0)

(https://creativecommons.org/licenses/by-nc/4.0/), which permits remixing, adapting and building upon the work for non-commercial use, provided the original work is properly cited. 